\title{
Bio-Hydrogen Production: A Promising Strategy for Organic Waste Management
}

\author{
Satinder Kaur Brar* and Saurabh Jyoti Sarma \\ INational Institute of Scientific Research Center - Water, Earth and Environment, 490, rue de la Couronne, Quebec (Quebec)
}

Waste materials could be broadly subdivided as industrial waste, municipal waste, agricultural waste as well as other hazardous wastes [1]. Out of these categories, they could be further classified as organic waste materials such as food processing waste, organic wastes generated by industries, crop residues and animal manures generated from agricultural practices, organic fraction of municipal waste [2]; and inorganic waste and relatively inert bulky wastes, such construction and demolition waste. With the increase in global population, both the amount of waste generated and the rate of waste generation are increasing. For example, annually United Kingdom alone is producing around 500 million tons of wastes out of which, nearly 40 percent being agricultural waste [3]. Similar to agriculture, well established manufacturing and distribution systems also have a major role in waste generation. According to a claim, the waste generated during such processes is often ten times higher than the amount of finished product obtained [3]. Landfilling is probably the easiest way for waste disposal which has been practiced globally and according to a report; nearly 80 percent of waste is disposed of to landfill sites [3].

However, the organic waste materials, if disposed of to the landfill sites are converted to methane by the activity of methanogen; and it is considered as a source of greenhouse gas emission. Therefore, different governments have devised strict regulations to minimize the disposal of the waste with high organic content to landfill sites. For example, Germany bans landfill disposal of waste wood and waste containing more than 5\% total organic carbon; Austria bans landfill disposal of waste with more than $3 \%$ total organic carbon; Denmark bans sending of combustible waste into such sites [4]. Such activities are clear indication of the interest of global community for the treatment of organic wastes by environmentally sustainable approaches. In this context, utilization of such waste for the recovery of energy or production of valuable chemicals and fertilizers are some of the possibilities [2]. In its simplest form of application, organic wastes could be used as a fertilizer to agricultural fields; however, it has certain disadvantages. For example, sometimes the amount of waste is too high to be applied on agricultural land. Likewise, structural nature of the waste materials could be a problem during its application in field. Further, nutrient content could vary with the type of the waste, making it difficult to predict its effect on crop productivity. Moreover, environmental issues, such as spreading of pathogens and unpleasant odor as well as possible emission of ammonia and other gases are the other drawbacks of direct application of organic wastes to the agricultural fields [2]. Production of bio-fuels, such as biogas, bioethanol and biodiesel and other biochemicals are the other options for sustainable utilization of organic waste materials. However, each of these options also has certain issues. For example, biogas is known to have lower heating value and due to the presence of a small fraction of $\mathrm{H}_{2} \mathrm{~S}$ with corrosive property, it may damage the engine $[5,6]$. Also, biogas should be preferentially utilized near the production facility as it has difficulties in transportation. Likewise, considering possible wide spread application of biogas, accidental release of $\mathrm{CH}_{4}$ to the atmosphere during biogas production could be an issue. A number of industrial chemical (ranging from organic acids to solvents) could also be produced by utilizing organic waste material. However, mainly due to complex nature (presence of impurities) of organic waste, downstream processing of such processes is complicated. Thus, production of gaseous product (apart from conventional biogas), which readily separates from the fermentation medium, has high potential as a means of organic waste valorization.

In this context, bio-hydrogen production by bioconversion of organic waste is a promising strategy. Unlike conventional biofuels (biogas, bioethanol, biodiesel) and fossil fuels, hydrogen produces only water as the byproduct of its combustion; and hence, it is considered as one of the clean renewable energy carrier for future. Energy density of hydrogen may vary between $120-142 \mathrm{MJ} / \mathrm{Kg}$ (higher than fossil fuels), and in terms of energetic value $1 \mathrm{Kg}$ of hydrogen can replace nearly $3.55 \mathrm{~L}$ of conventional diesel [7]. For energy conversion, hydrogen can either be used in fuel cell to generate electricity or in internal combustion engine [8]. At present, hydrogen is mostly produced by thermo-chemical processes such as steam reforming of natural gas and coal gasification etc. However, due to the depletion of fossil fuel reserves as well as environmental concern such as greenhouse gas emission, exploration of other sustainable methods of hydrogen production is becoming inevitable. Thus, biological hydrogen production from waste organic material has gained significant importance.

Dark fermentation, photo-fermentation and application of microbial electrolysis cell are the major methods of bio-hydrogen production using organic materials. Among these methods, dark fermentative hydrogen production is the mostly investigated approach. For the production of $\mathrm{H}_{2}$ by this approach, anaerobic bacteria (both strict and facultative anaerobe) are used, which convert the organic materials mainly to hydrogen, carbon dioxide; and different organic acids and solvents are also produced as fermentation end-products. Due to the production of such end-products, a portion of the substrate is compromised and the process fails to obtain theoretically possible $\mathrm{H}_{2}$ yield. Similarly, simultaneous organic acid production results in sharp decrease of medium $\mathrm{pH}$ and termination of the process. Two stage dark and photo fermentation is often considered as one solution for these problems; where the end products of dark fermentation are utilized in a subsequent photo-fermentative hydrogen production stage. However, it will be better to develop a single stage process (as the operation cost of two independent processes of a two stage processes could be a problem for its large scale production), where the end-products of dark

*Corresponding author: Satinder Kaur Brar, Institut National de la Recherche Scientifique, Centre - Eau Terre Environnement, 490, rue de la Couronne Québec (Québec) G1K 9A9, Tel: 418 654-3116; Fax: 418 654-2600; E-mail: Satinder.Brar@ete.inrs.ca

Received May 23, 2013; Accepted May 28, 2013; Published June 08, 2013

Citation: Brar SK, Sarma SJ (2013) Bio-Hydrogen Production: A Promising Strategy for Organic Waste Management. Hydrol Current Res S5:e002. doi:10.4172/2157-7587.S5-e002

Copyright: () 2013 Brar SK, et al. This is an open-access article distributed under the terms of the Creative Commons Attribution License, which permits unrestricted use, distribution, and reproduction in any medium, provided the original author and source are credited. 
Citation: Brar SK, Sarma SJ (2013) Bio-Hydrogen Production: A Promising Strategy for Organic Waste Management. Hydrol Current Res S5:e002. doi:10.4172/2157-7587.S5-e002

Page 2 of 2

fermentation could be simultaneously utilized within the same process. A suitable co-culture of two different microorganisms is an interesting option in this regard.

Microbial electrolysis cell is the other promising method of biohydrogen production from organic waste material. In this approach, a microbial reactor is used as the anode chamber of the cell, where the microorganism oxidizes the substrate such as acetate to generate

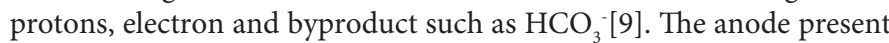
in the chamber serves as electron acceptor and by applying an external voltage of as low as $0.2 \mathrm{~V}$; protons generated during the process could be reduced to hydrogen [10]. During dark fermentative hydrogen production, from each molecule of glucose, maximum four hydrogen could be obtained (due to thermodynamic limitation); whereas, the byproduct of such process (e.g. acetate) could be used as a substrate in microbial electrolysis cell and it has the potential to produce additional eight molecules of hydrogen [9]. Thus, microbial hydrogen production could be considered as an attractive strategy for organic waste valorization and reduction of process cost along with high yield patterns seems to be the biggest challenge for successful industrial production of bio-hydrogen.

\section{References}

1. http://www.unescap.org/esd/environment/soe/2000/documents/CH08.PDF.

2. Westerman P, Bicudo J (2005) Management considerations for organic waste use in agriculture. Bioresource Technol 96: 215-221.

3. Population, waste and chemicals 107-110.

4. Alexander Neubauer (2007) Convergence with EU Waste Policies. Short Guide for ENP Partners and Russia.

5. http://www.cense.no/getfile.php/CenSE/Applied\%20energy\%20paper\%2001. pdf.

6. http://www.ijetae.com/files/Conference\%20ICERTSD2013/IJETAE_ ICERTSD_0213_31.pdf.

7. Sarma SJ, Brar SK, Le Bihan Y, Buelna G (2013) Bio-hydrogen production by biodiesel-derived crude glycerol bioconversion: a techno-economic evaluation. Bioprocess and Biosyst Eng 36: 1-10.

8. http://www.airproducts.com/industries/Energy/Power/Power-Generation/ hydrogen-basics.aspx.

9. Geelhoed JS, Hamelers HVM, Stams AJM (2010) Electricity-mediated biological hydrogen production. Curr Opin Microbiol 13: 307-315.

10. Xiao Li, Wen Z, Ci S, Chen J, He Z (2012) Carbon/iron-based nanorod catalysts for hydrogen production in microbial electrolysis cells. Nano Energy 1: 751-756.
This article was originally published in a special issue, Energy Recovery from Municipal \& Industrial Wastes handled by Editor(s). Satinder Kaur Brar, University of Quebec, Canada 